\title{
Foliar nutrient content and maize yield with vinasse application during three crops
}

\author{
Samuel Ferreira da Silva ${ }^{1} \oplus$, Giovanni de Oliveira Garcia' ${ }^{1}$, Edvaldo Fialho dos $\operatorname{Reis}^{1} \oplus$, Leandro Pin Dalvi ${ }^{1} \odot$ \\ 1 Universidade Federal do Espírito Santo, Centro de Ciências Agrárias e Engenharias, Alegre-ES, Brasil. E-mail: samuelfd.silva@yahoo.com.br; giovanni.garcia@ufes.br; \\ edreis@cca.ufes.br; leandro.dalvi@ufes.br
}

ABSTRACT: The objective with this study was to study the changes in foliar nutrient content and grain yield of maize crop with the application of vinasse doses during three crops. The study was developed under field conditions in the municipality of Alegre, ES, during 2013, 2014 and 2015. Each cultivar was set up following a scheme of subdivided plots in a randomized block design with six treatments and four replicates. The treatments were composed by mineral fertilization (NPK) and five vinasse dosages, corresponding to 50,100, 150, 200 and $250 \mathrm{~m}^{3}$ ha $^{-1}$. In the leaf samples, the contents of N, P, K, S, Ca, Mg, B, Cu, Fe and Zn were analyzed. In addition, the grain yield for each treatment was also evaluated. Based on the obtained results, the agricultural use of vinasse at doses higher than $50 \mathrm{~m}^{3} \mathrm{ha}^{-1}$ promoted the leaf contents of $\mathrm{N}, \mathrm{P}, \mathrm{K}, \mathrm{S}, \mathrm{Ca}, \mathrm{Mg}$ and $\mathrm{B}$ similar to the result attained by supplying mineral fertilization, in the three crops. Regarding grain yield, the best perfomances were obtained at the dosages corresponding to $150 \mathrm{~m}^{3} \mathrm{ha}^{-1}$ for the years of 2013 and 2014 and $100 \mathrm{~m} 3 \mathrm{ha}-1$ for the year of 2015, with a production higher than 12 t ha $^{-1}$ in the three crops.

Key words: agricultural yield; effluent application; leaf nutrition; organic residue; Zea mays L.

\section{Teores foliares de nutrientes e produtividade do milho com aplicação de vinhaça durante três safras}

RESUMO: Objetivou-se estudar as alterações nos teores foliares de nutrientes e a produção de grãos da cultura do milho com a aplicação de doses de vinhaça, durante três safras. $O$ estudo foi desenvolvido em condições de campo no município de Alegre, ES, nos anos de 2013, 2014 e 2015. Cada cultivo foi instalado seguindo um esquema de parcelas subdivididas em um delineamento em blocos casualizados com seis tratamentos e quatro repetições. Os tratamentos foram compostos pela adubação mineral (NPK) e cinco doses de vinhaça, correspondentes a 50, 100, 150, 200 e $250 \mathrm{~m}^{3} \mathrm{ha}^{-1}$. Nas amostras foliares foram analisados os teores de N, P, K, S, Ca, Mg, B, Cu, Fe e Zn. Além disso, foi avaliada a produção de grãos referente a cada tratamento. Com base nos resultados obtidos, observou-se que o uso agrícola da vinhaça nas doses superiores a $50 \mathrm{~m}^{3}$ ha $^{-1}$ promoveram teores foliares de $\mathrm{N}, \mathrm{P}, \mathrm{K}, \mathrm{S}, \mathrm{Ca}, \mathrm{Mg}$ e B semelhantes àqueles obtidos com o fornecimento da adubação mineral, nas três safras. Quanto à produção de grãos, os melhores rendimentos foram obtidos nas doses correspondentes a $150 \mathrm{~m}^{3}$ ha-1, para os anos de 2013 e 2014 e $100 \mathrm{~m}^{3}$ ha-1 para o ano de 2015, com uma produção superior a 12 t ha ${ }^{-1}$, nas três safras.

Palavras-chave: produtividade agrícola; aplicação de efluente; nutrição foliar; resíduo orgânico; Zea mays L. 


\section{Introduction}

Among the industries that generate considerable effluent volume in Brazil, the sugar and the alcohol sector stand out, which according to data from Conab (2016), in the 2015/16 crop, 10.87 million hectares of planted area produced 665.58 million tons of sugarcane and 30.46 billion liters of ethanol.

In the production stages of this sector, a liquid residue known as vinasse is generated, in which is estimated that for each liter of ethanol or spirit produced, about 10 to 14 liters of vinasse is obtained (Mapa, 2007; Silva et al., 2014). Considering the current annual production of ethanol and spirits of 30.46 and 1.80 billion liters, respectively, and taking into account the technological level of national distilleries, the mean production is of $\mathbf{3 8 7 . 1 2}$ billion liters of vinasse each year.

Developed researches aiming at the agricultural use of this vinasse, point to this activity as an alternative of properly disposing this residue, since when used with technical criteria, vinasse has the potential of improving yield rates of interest crops and reducing the need of using mineral fertilization (Jiang et al., 2012; Christofoletti et al., 2013).

However, when applied with no technical criteria, it can cause undesirable effects, such as compromising the quality of the produced crop, in addition to changes in the chemical, physical and microbiological attributes of the soil (Lamaison et al., 2015).

Given the above, this research aimed to study the changes in leaf nutrient content and the grain production in the maize crop, resulting from the application of vinasse dosages, during three crops, in the Jerusalem rural community, municipality of Alegre, ES.

\section{Materials and Methods}

The experiment was conducted in field conditions during the years of 2013, 2014 and 2015, in the Jerusalem rural community, municipality of Alegre, ES. The site is located under the geographical coordinates of $41^{\circ} 32^{\prime} 58$ 'W longitude and $20^{\circ} 47^{\prime} 11^{\prime} \mathrm{S}$ latitude. The soil in the study area was classified as a clayey Red-Yellow Latosol (Oxisol) (Embrapa, 2013).

According to the Köppen international classification, the predominant climate in the region is the Cwa type, characterized by a dry winter and rainy summer. The accumulated precipitation and the average monthly temperature in the Jerusalem rural community, municipality of Alegre, ES, during the study period (Figure 1), were obtained through the automatic weather station of Alegre A617 (Inmet, 2018), and by using a pluviometer installed in the study area.

The experiment was set up in a randomized block design with six treatments and four replicates. The treatments were composed by mineral fertilization after the sowing (NPK) and five vinasse dosages, corresponding to 50, 100, 150, 200 and $250 \mathrm{~m}^{3} \mathrm{ha}^{-1}$. Mineral fertilization was based on the Fertilization and Lime Recommendation Manual for the Espírito Santo State (Prezotti et al., 2007). As a mineral fertilization source, granulated urea $(45 \% \mathrm{~N})$, simple granulated superphosphate $\left(18 \% \mathrm{P}_{2} \mathrm{O}_{5}\right)$ and granulated potassium chloride $\left(60 \% \mathrm{~K}_{2} \mathrm{O}\right)$ were used.

Total occupied area of the experiment was of $190.08 \mathrm{~m}^{2}$, with the experimental plots measuring $2.20 \times 3.60 \mathrm{~m}(7.92$ $\mathrm{m}^{2}$ ). Therefore, each experimental unit was composed by four $2.20 \mathrm{~m}$-long rows, spaced $0.90 \mathrm{~m}$ apart from each other. In each of these rows, 11 pits were opened, spaced $0.20 \mathrm{~m}$ apart among themselves. Each experimental plot was fixed, thus the experiment was set up in the same location in the three crops, with each plot consisting of 44 plants from the AG 1051 hybrid maize, grown in the spacing of $0.20 \mathrm{~m}$ between pits and 0.90 $\mathrm{m}$ between rows. Sowing was carried out in September of each one of the three years.

Excluding the border, the useful area of each experimental plot, where the variables were obtained, corresponded to $1.60 \times 1.80 \mathrm{~m}\left(2.88 \mathrm{~m}^{2}\right)$, with a total of 16 useful plants, in which they were collected for conducting analyzes.

The vinasse used in the experiment was collected in a spirit production unit close to the place where the experiment was

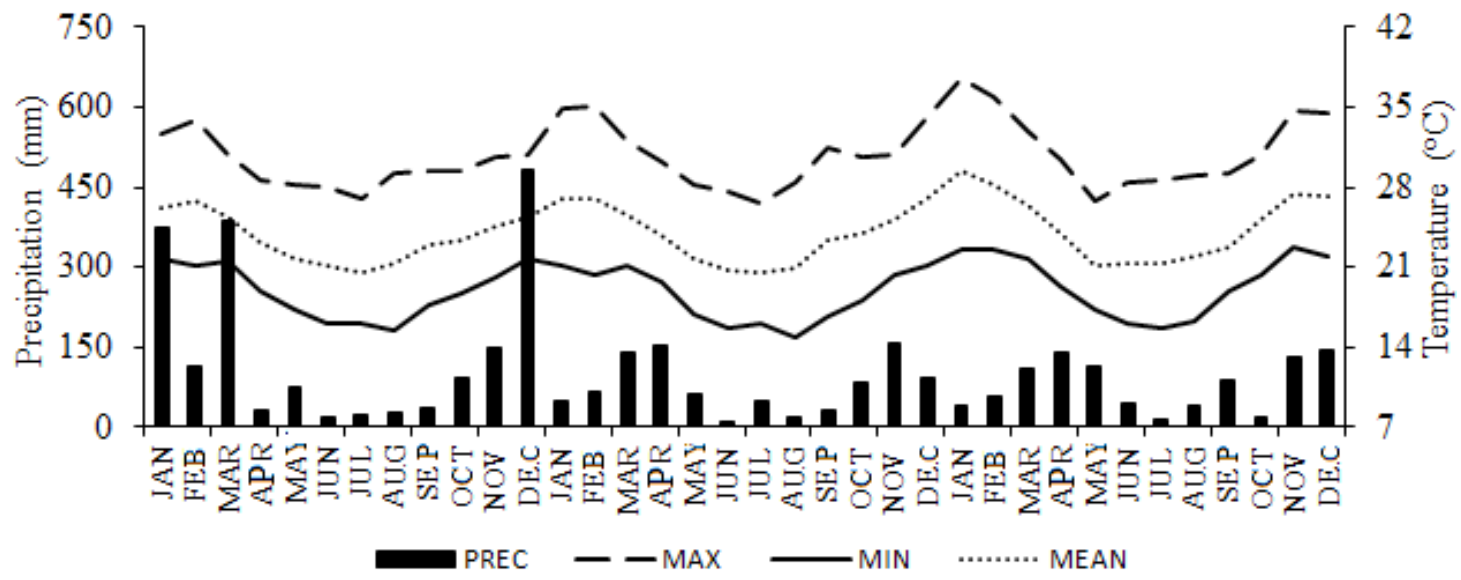

Source: Inmet (2018) for temperature, and pluviometer installed in the study area for precipitation.

Figure 1. Accumulated monthly precipitation (PREC) and maximum (MAX), minimum (MIN) and monthly average (AVG) temperatures, in the Jerusalem rural community, municipality of Alegre, ES, during the years of 2013, 2014 and 2015. 
conducted. For its chemical characterization, an $800 \mathrm{~mL}$ sample was collected and sent to the laboratory (Table 1). Each year, a new analysis was held on the vinasse before its application.

Vinasse was manually applied assisted by a watering can with a shower-type outlet, ensuring that no runoff would occur. Vinasse supplying occured in a single application, when the crop had 3 to 5 leaves. At the same time, post-sowing mineral fertilization (NPK) was held for the plots corresponding to this fertilization.

Concerning the evaluation of the crop nutritional status, the used leaves were sampled when $50 \%$ of the plants displayed bolting, approximately in the 10th post-germination week. For this, in the useful area of each experimental plot, the middle third of the opposite leaf and below the ear (diagnostic leaf) were collected (Coelho \& França, 1995). In the leaf samples, the contents of nitrogen, phosphorus, potassium, sulfur, calcium, magnesium, boron, copper, iron and zinc were all analyzed.

As for grain production, the harvest was performed when the ears had dry grain characteristics. Evaluated agronomic variables in the maize ears at the harvesting time were: whole ear weight $(\mathrm{g})$, grains weight after threshing the ears (g) and the grain production per hectare $\left(\mathrm{t} \mathrm{ha}^{-1}\right)$, which was obtained by multiplying the mean grains weight per ear by the estimate of the mean production of ears per hectare. The three crops were manually harvested.

The soil in the experimental area was prepared for the cultivation with mechanical cleaning, by means of a rotary cutter, prior to the sowing beginning. In order to avoid competition with invasive plants throughout the experiment, regular weedings were held, thus enabling the crop to develop without having to compete with invasive plants for water and nutrients during its cycle.

Regarding phytosanitary control, periodic visits were made to the experimental area, not verifying any presence of pests or diseases, and thus there was no need to hold any phytosanitary control practices.

Obtained results were analyzed separately for each year (2013, 2014 and 2015). The statistical analysis of these results was performed by analysis of variance, adopting a $5 \%$ probability. The comparison of the treatment means (vinasse dosages) in relation to the control group (mineral fertilization) was by the Dunnett test at $5 \%$ probability (Banzatto \& Kronka, 2006).

\section{Results and Discussion}

By analyzing the obtained results, after the analysis of variance, it was verified that vinasse application in the maize crop provided significant changes $(\alpha \leq 0.05)$ in the contents of macro and micronutrients in leaf tissue. Thus, Table 2 shows that the leaf contents of $\mathrm{N}, \mathrm{P}, \mathrm{K}$ and $\mathrm{Ca}$, in the plots that had the vinasse application of 100,150, 200 and $250 \mathrm{~m}^{3} \mathrm{ha}^{-1}$, did not show significant difference in relation to the mineral fertilization treatment (NPK), in the three evaluated years.

In turn, the leaf contents of these nutrients were lower for the $50 \mathrm{~m}^{3}$ ha-1 dosage, in the three years. Therefore, with the exception of the one corresponding to $50 \mathrm{~m}^{3} \mathrm{ha}^{-1}$, the other applied vinassage dosages supplied the crop nutritional demand, with no significant difference in the results obtained with the mineral fertilizer application.

This absorption of macro and micronutrients by the crop, in the plots that had application of vinasse dosages above 50 $\mathrm{m}^{3} \mathrm{ha}^{-1}$ in the three years, can be associated with the fact that it had enabled a greater nutrients supply to the soil (Malavolta, 2008; Taiz \& Zeiger, 2013).

Moreover, the organic matter, supplied to the soil via vinasse, has the ability to complex the exchangeable aluminum which in turns raises the soil $\mathrm{pH}$, so its cation exchange capacity is naturally increased, and the exchangeable cations are also in greater concentration in the soil exchange complex (Hagvall et al., 2015; Zhao et al., 2017).

Such behavior may partly justify the greater accumulation of some cations such as calcium and magnesium in the maize crop leaf tissue, in the plots that received the vinasse dosages of 200 and $250 \mathrm{~m}^{3} \mathrm{ha}^{-1}$, when in comparison to those that received the mineral fertilization or other dosages $(50,100$ and $150 \mathrm{~m}^{3} \mathrm{ha}^{-1}$ ), mainly in 2015 .

When applying vinasse, the foliar nitrogen and sulfur contents, with the exception of the $50 \mathrm{~m}^{3} \mathrm{ha}^{-1}$ dosage, showed values within the acceptable limit for the crop, while the mineral fertilization conditioned contents of this element below the minimum required in 2013 , which can contribute to a reduction in crop production (Furlani, 2004; Taiz \& Zeiger, 2013).

However, in 2014 and 2015, except for the $50 \mathrm{~m}^{3} \mathrm{ha}^{-1}$ dosage, the absorption of both nutrients was adequate in the plots that received vinasse, as well as in the plots that received mineral fertilization. In a similar manner, for the leaf

Table 1. Chemical characterization of the used vinasse in the three years.

\begin{tabular}{|c|c|c|c|c|c|c|c|}
\hline \multirow{2}{*}{ Characteristic $^{1}$} & \multicolumn{3}{|c|}{ Value } & \multirow{2}{*}{ Characteristic $^{1}$} & \multicolumn{3}{|c|}{ Value } \\
\hline & 2013 & 2014 & 2015 & & 2013 & 2014 & 2015 \\
\hline $\mathrm{pH}$ & 3.57 & 3.05 & 3.19 & $\mathrm{Fe}\left(\mathrm{mg} \mathrm{L}^{-1}\right)$ & 15.00 & 37.00 & 48.00 \\
\hline $\mathrm{N}\left(\mathrm{mg} \mathrm{L}^{-1}\right)$ & 250.00 & 326.00 & 288.00 & $\mathrm{Zn}\left(\mathrm{mg} \mathrm{L}^{-1}\right)$ & 2.00 & 6.00 & 14.00 \\
\hline$P\left(m g L^{-1}\right)$ & $1,812.00$ & $1,943.00$ & $2,024.00$ & $\mathrm{Cu}\left(\mathrm{mg} \mathrm{L}^{-1}\right)$ & 7.00 & 12.00 & 27.00 \\
\hline$K\left(\mathrm{mg} \mathrm{L}^{-1}\right)$ & $3,218.00$ & $2,981.00$ & $2,743.00$ & $M n\left(m g L^{-1}\right)$ & 4.00 & 8.00 & 9.00 \\
\hline $\mathrm{Ca}\left(\mathrm{mg} \mathrm{L}^{-1}\right)$ & 70.00 & 54.00 & 62.00 & $\mathrm{~B}\left(\mathrm{mg} \mathrm{L}^{-1}\right)$ & 1.00 & 2.00 & 5.00 \\
\hline $\mathrm{Mg}\left(\mathrm{mg} \mathrm{L}^{-1}\right)$ & 93.00 & 71.00 & 64.00 & $\mathrm{Na}\left(\mathrm{mg} \mathrm{L}^{-1}\right)$ & 340.00 & 286.00 & 300.00 \\
\hline $\mathrm{S}\left(\mathrm{mg} \mathrm{L}^{-1}\right)$ & 220.00 & 162.00 & 139.00 & $\mathrm{MO}\left(\mathrm{mg} \mathrm{L}^{-1}\right)$ & $5,660.00$ & $4,430.00$ & $5,090.00$ \\
\hline
\end{tabular}

${ }^{1}$ Methodology (Mapa, 2007). MO: Organic matter. Analyzes carried out at the Soil and Water Resources Laboratory of the Center for Agricultural Sciences and Engineering at the Federal University of Espírito Santo (CCAE-UFES). 
Table 2. Mean values of nutritional contents in the leaf tissue of the maize crop as a function of mineral fertilization and vinasse in the three years.

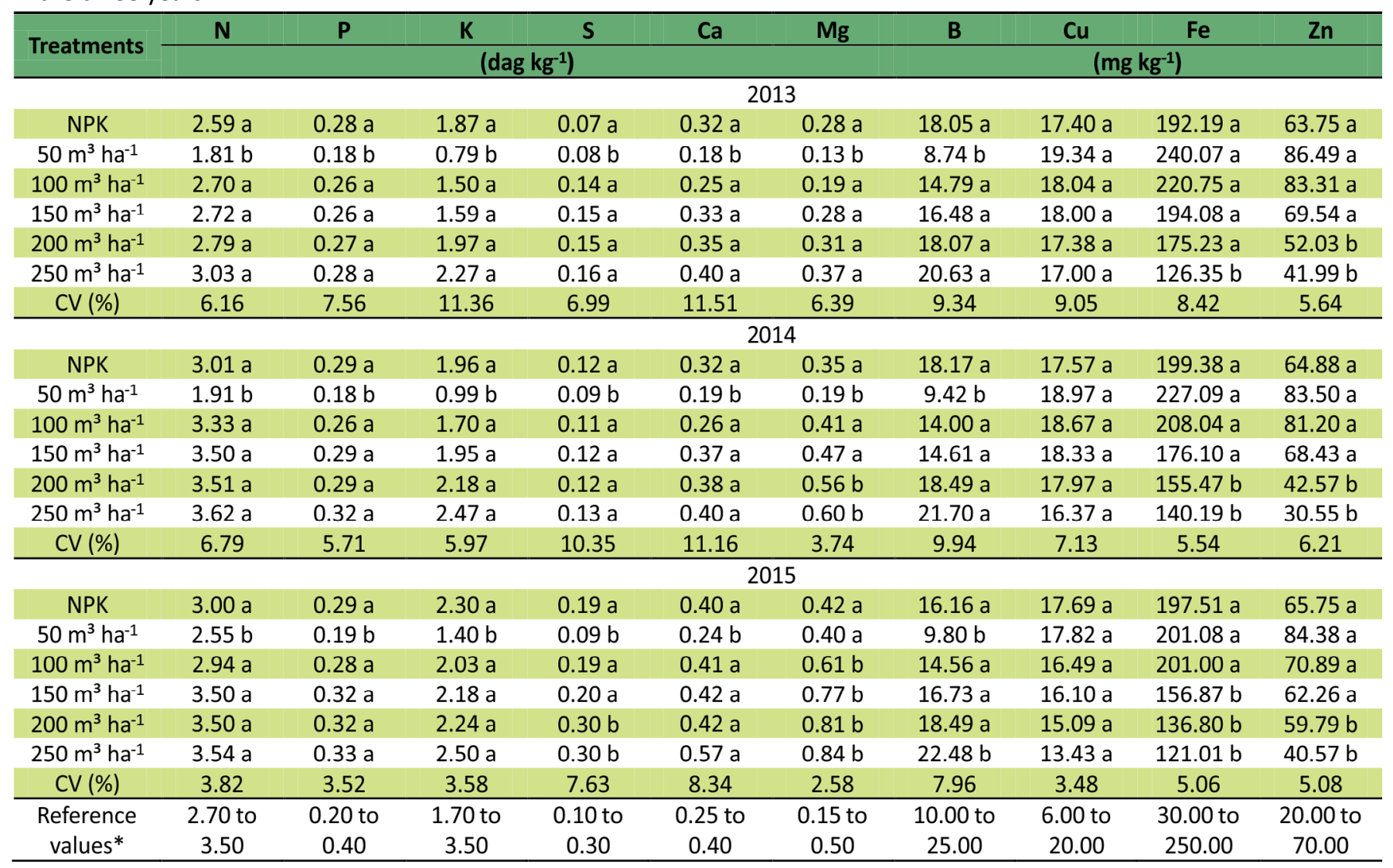

Means followed by the same lowercase letter in the column do not differ statistically from the NPK fertilization (control), at the level of $5 \%$ probability by Dunnett's test. CV (\%): Coefficient of variation. *Leaf contents of macro and micronutrients considered as adequate for the maize crop development (Martinez et al., 1999; Prezotti et al., 2007).

phosphorus contents, with except for the $50 \mathrm{~m}^{3}$ ha-1 dosage, when applying vinasse or mineral fertilization, the leaf content of this nutrient was within the limit considered as appropriate (from 0.20 to $0.40 \mathrm{dag} \mathrm{kg}^{-1}$ ), in the three years.

Regarding foliar potassium content, the vinasse used in this study has a mean potassium concentration of $2.98 \mathrm{~g} \mathrm{~L}^{-1}$ (Table 1), thus the potassium content added to the soil that received the highest vinasse dosage was significantly higher than the plots that received the lowest dosages. This reflected directly on the leaf potassium content in maize plants, so that in the plots that received $250 \mathrm{~m}^{3} \mathrm{ha}^{-1}$ of vinasse, the leaf potassium content was $21.39 ; 26.02$ and $8.69 \%$ above that obtained in the parcel that received mineral fertilizer, in the years of 2013, 2014 and 2015, respectively.

According to Hagvall et al. (2015), the application of organic residues to the soil enables a more stable environment due to the organic matter contribution, which in turn allows a greater concentration of binding substances, having as one of its characteristics the retention of these cations.

In a similar way, in the experiment implemented by Basso et al. (2013) in a maize cultivation with vinasse application, when compared to the cultivation done by means of conventional management, increases in the concentrations of potassium and nitrogen in the crop leaf tissue were observed with the rising vinasse dosages. The same pattern was observed in the present study.
With the exception of zinc, the micronutrients boron, copper and iron in the maize leaf tissue were within the maximum limit defined as acceptable for the crop, regardless of the applied vinasse dosage, in the three years. However, the leaf boron content in the dose corresponding to $50 \mathrm{~m}^{3}$ $\mathrm{ha}^{-1}$ of vinasse was below the adequate, with contents of 8.74; 9.42 and $9.80 \mathrm{mg} \mathrm{kg}^{-1}$, for the years of 2013, 2014 and 2015, respectively, which represents an average deficit of $6.80 \%$ of boron in the crop leaf tissue, in the three years. For the other applied dosages, the boron content were adequate.

For zinc levels, in the years of 2013, 2014 and 2015, in the doses corresponding to 50 and $100 \mathrm{~m}^{3} \mathrm{ha}^{-1}$ of vinasse, there was a leaf accumulation above $70 \mathrm{mg} \mathrm{kg}^{-1}$, which can compromise the crop development (Martinez et al., 1999; Prezotti et al., 2007). However, in the other applied dosages, the found contents were adequate to the maize crop, in the three evaluated years.

In addition, the availability of the micronutrients copper, iron and zinc rises in soils with lower pH (Garcia-Mina et al., 2004). Therefore, in the present study, with the vinasse agricultural use, there was an inverse situation due to the rising $\mathrm{pH}$ of the soil, which partly explains the reductions verified in these micronutrients leaf contents in maize plants.

Regarding grain production, Table 3 shows that the mean weight of ears and of grains had a similar behavior in the three evaluated years, with a production lower than that 
obtained when supplying mineral fertilizer, in the vinasse dose corresponding to $50 \mathrm{~m}^{3} \mathrm{ha}^{-1}$. However, there were no significant differences for these variables in the other applied vinasse dosages in relation to mineral fertilization, in the three years.

Table 3 also shows that grain production at doses corresponding to both 50 and $250 \mathrm{~m}^{3}$ ha-1 of vinasse were lower than the production found when supplying mineral fertilizer in the three years. However, at 100 and $150 \mathrm{~m}^{3} \mathrm{ha}^{-1}$ dosages, the production attained was higher than the when mineral fertilizer (NPK) was applied, in the years 2013 and 2014.

In the following year, this result was repeated only at the dose equivalent to $100 \mathrm{~m}^{3} \mathrm{ha}^{-1}$ of vinasse. In turn, the doses corresponding to 100,150 and $200 \mathrm{~m}^{3} \mathrm{ha}^{-1}$ conditioned the grain production without a significant difference from that found with the mineral fertilization application, in the three years (Table 3 ).

Such obtained results, displayed in Table 3, demonstrate that in up to three crops, the application of vinasse dosages between 100 and $250 \mathrm{~m}^{3} \mathrm{ha}^{-1}$ in a maize production system enabled grain production per ear without significant differences in relation to the mineral fertilization, demonstrating the agronomic potential of this residue.

In this aspect, grain production is considered as the most noble and profitable portion of the ear and it is desirable that its proportion in relation to the ear weight is as high as possible. In

Table 3. Mean values of the total ear weight, grain weight and total grain production per hectare of the maize crop as a function of mineral fertilization and vinasse in the three years.

\begin{tabular}{|c|c|c|c|}
\hline \multirow{2}{*}{ Treatments } & Ear weight & Grains weight & \multirow{2}{*}{$\begin{array}{c}\text { Grains } \\
\text { yield (t ha-1) }\end{array}$} \\
\hline & \multicolumn{2}{|c|}{ (g) } & \\
\hline & \multicolumn{3}{|c|}{2013} \\
\hline NPK & $318.71 \mathrm{a}$ & 228.61 a & $11.43 \mathrm{a}$ \\
\hline $50 \mathrm{~m}^{3} \mathrm{ha}^{-1}$ & $237.43 b$ & $172.93 \mathrm{~b}$ & $8.65 b$ \\
\hline $100 \mathrm{~m}^{3} \mathrm{ha}^{-1}$ & $336.69 a$ & $235.24 \mathrm{a}$ & $11.76 \mathrm{a}$ \\
\hline $150 \mathrm{~m}^{3} \mathrm{ha}^{-1}$ & 371.34 a & 244.92 a & $12.24 \mathrm{a}$ \\
\hline $200 \mathrm{~m}^{3} \mathrm{ha}^{-1}$ & 290.55 a & 209.30 a & $10.47 a$ \\
\hline $250 \mathrm{~m}^{3} \mathrm{ha}^{-1}$ & $282.25 \mathrm{a}$ & $187.57 \mathrm{a}$ & $9.38 \mathrm{~b}$ \\
\hline \multirow[t]{2}{*}{ CV (\%) } & 5.90 & 9.13 & 13.00 \\
\hline & \multicolumn{3}{|c|}{2014} \\
\hline NPK & $349.06 \mathrm{a}$ & $242.24 \mathrm{a}$ & $12.11 \mathrm{a}$ \\
\hline $50 \mathrm{~m}^{3} \mathrm{ha}^{-1}$ & $252.40 \mathrm{~b}$ & $177.81 b$ & $8.89 \mathrm{~b}$ \\
\hline $100 \mathrm{~m}^{3} \mathrm{ha}^{-1}$ & $354.33 \mathrm{a}$ & 245.87 a & $12.29 a$ \\
\hline $150 \mathrm{~m}^{3} \mathrm{ha}^{-1}$ & 383.37 a & 250.97 a & $12.55 \mathrm{a}$ \\
\hline $200 \mathrm{~m}^{3} \mathrm{ha}^{-1}$ & $303.86 \mathrm{a}$ & $214.32 \mathrm{a}$ & $10.72 a$ \\
\hline $250 \mathrm{~m}^{3} \mathrm{ha}^{-1}$ & $269.22 \mathrm{a}$ & $198.26 \mathrm{a}$ & $9.91 \mathrm{~b}$ \\
\hline \multirow[t]{2}{*}{ CV (\%) } & 11.12 & 7.16 & 10.30 \\
\hline & \multicolumn{3}{|c|}{2015} \\
\hline NPK & 382.88 a & 259.61 a & $12.98 \mathrm{a}$ \\
\hline $50 \mathrm{~m}^{3} \mathrm{ha}^{-1}$ & $267.57 b$ & $178.33 b$ & $8.92 b$ \\
\hline $100 \mathrm{~m}^{3} \mathrm{ha}^{-1}$ & $387.06 \mathrm{a}$ & $262.05 \mathrm{a}$ & $13.10 \mathrm{a}$ \\
\hline $150 \mathrm{~m}^{3} \mathrm{ha}^{-1}$ & 397.67 a & $258.12 \mathrm{a}$ & $12.91 \mathrm{a}$ \\
\hline $200 \mathrm{~m}^{3} \mathrm{ha}^{-1}$ & 305.37 a & 204.21 a & $10.21 \mathrm{a}$ \\
\hline $250 \mathrm{~m}^{3} \mathrm{ha}^{-1}$ & 290.15 a & 193.71 a & $9.69 \mathrm{~b}$ \\
\hline CV (\%) & 8.17 & 8.80 & 11.90 \\
\hline
\end{tabular}

Means followed by the same lowercase letter in the column do not differ statistically from the NPK fertilization (control), at the level of $5 \%$ probability by Dunnett's test. CV (\%): Coefficient of variation.

OBS: Total grain yield was found by multiplying the mean grain weight per ear by the estimated ear yield, which was of 50,000 ears per hectare. this sense, the present study showed that the mean proportion of grains produced per ear, in the first year (2013), was 69.87 and $71.73 \%$ with the application of the dose equivalent to 100 $\mathrm{m}^{3} \mathrm{ha}^{-1}$ of vinasse and mineral fertilization, respectively. These results are in agreement with those obtained by Mendes et al. (2013), applying nitrogen fertilizer sources in the cultivation of maize hybrids, obtaining in some cases a proportion of grains less than $50 \%$ of the total ear weight.

In a similar manner, in the experiment implemented by Gott et al. (2014), when cultivating hybrid maize for grain production, a mean production of around $9.00 \mathrm{t} \mathrm{ha}^{-1}$ of grain was obtained in a conventional cultivation system with the supply of different nitrogen sources. These results are below those obtained in the present study, since with the exception of the $50 \mathrm{~m}^{3}$ ha-1 dosage, an estimated production above 9.30 $\mathrm{t} \mathrm{ha} \mathrm{a}^{-1}$ of grain was verified in the three years, with the mineral fertilizer application and other vinasse dosages.

However, according to Embrapa Milho e Sorgo, the productive potential of grains in Brazil is greater than 16.00 $\mathrm{t} \mathrm{ha}^{-1}$, yet the national mean production in the 2014/15 crop was of $5.01 \mathrm{t} \mathrm{ha}^{-1}$. For the state of Espírito Santo, the mean grain production was lower, reaching $2.18 \mathrm{t} \mathrm{ha}^{-1}$ in the same crop (Conab, 2016). Hence, under the conditions in which the present study was developed, it was possible to achieve a grain production higher than the national mean and that of the Espírito Santo state, both for the application of mineral fertilization and for the vinasse dosages.

Therefore, if used with technical criteria and in suitable dosages, vinasse becomes a by-product of agronomic interest, presenting real possibilities of use in agricultural crops, as it was demonstrated with the results found in the present study.

\section{Conclusions}

Vinasse dosages above $50 \mathrm{~m}^{3} \mathrm{ha}^{-1}$ promote leaf content of $\mathrm{N}, \mathrm{P}, \mathrm{K}, \mathrm{S}, \mathrm{Ca}, \mathrm{Mg}$ and $\mathrm{B}$, similar to those obtained with supplying mineral fertilizer, in the three crops.

Regarding grain yield, the best performances were obtained at the dosages corresponding to $150 \mathrm{~m}^{3} \mathrm{ha}^{-1}$, for 2013 and 2014, with production greater than $12 \mathrm{t} \mathrm{ha}^{-1}$. In 2015, however, the best yield was obtained at a dosage corresponding to $100 \mathrm{~m}^{3} \mathrm{ha}^{-1}$, with a greater yield than $13 \mathrm{t}$ ha-1.

Vinasse dosages between 100 and $150 \mathrm{~m}^{3}$ ha $^{-1}$ promote grain yield results in the order of 12 to $13 \mathrm{t} \mathrm{ha}^{-1}$.

\section{Acknowlogdments}

To the Espírito Santo Research and Innovation Foundation (FAPES) for the financing support.

\section{Literature Cited}

Banzatto, D.A.; Kronka, S.N. Experimentação agrícola. 4.ed. Jaboticabal: FUNEP, 2006. 237p. 
Basso, C.J.; Santi, A.L.; Lamego, F.P.; Somavillai, L.; Brigo, T.J. Vinhaça como fonte de potássio: resposta da sucessão aveia-preta/milho silagem/milho safrinha e alterações químicas do solo na Região Noroeste do Rio Grande do Sul. Ciência Rural, v.43, n.4, p.596602, 2013. https://doi.org/10.1590/S0103-84782013000400006.

Christofoletti, C.A.; Escher, J.P.; Correia, J.E.; Marinho, J.F.U.; Fontanetti, C.S. Sugarcane vinasse: environmental implications of its use. Journal Waste Management, v.33, n.12, p.2752-2761, 2013. https://doi.org/10.1016/j.wasman.2013.09.005.

Coelho, A.M.; França, G.E. Seja o doutor do seu milho: nutrição e adubação. Piracicaba: Potafos, 1995. 25p. (Arquivo do agrônomo, n.2). http://brasil.ipni.net/ipniweb/region/brasil.nsf/0/81A0BBD 6E936445D83257AA0003A892E/\$FILE/Milho.pdf. 12 Out. 2018.

Campanhia Nacional de Abastecimento - Conab. Acompanhamento das safras brasileiras - 2015. https://www.conab.gov.br/infoagro/safras. 5 Ago. 2018.

Empresa Brasileira de Pesquisa Agropecuária - Embrapa. Sistema brasileiro de classificação de solos. 3.ed. Brasília: Embrapa, 2013. $353 p$.

Furlani, A.M.C. Nutrição mineral. In: Kerbauy, G.B. Fisiologia vegetal. Rio de Janeiro: Guanabara Koogan, 2004. p.40-75.

Garcia-Mina, J.M.; Antolín, M.C.; Sanchez-Dias, M. Metal-humic complexes and plant micronutriente uptake: a study based on different plant species cultivated in diverse soils types. Plant and Soil, v.258, n.1, p.57-68, 2004. https://doi.org/10.1023/ B:PLSO.0000016509.56780.40.

Gott, R.M.; Sichocki, D.; Aquino, L.A.; Xavier, F.O.; Santos, L.P.D.; Aquino, R.F.B. Fontes e épocas de aplicação de nitrogênio no milho safrinha. Revista Brasileira de Milho e Sorgo, v.13, n.1, p.24-34, 2014. https://doi.org/10.18512/1980-6477/rbms. v13n1p24-34.

Hagvall, K.; Persson, P.; Karlsson, T. Speciation of aluminum in soils and stream waters: The importance of organic matter. Chemical Geology, v.417, p.32-43, 2015. https://doi.org/10.1016/j. chemgeo.2015.09.012.

Instituto Nacional de Meteorologia - Inmet. Monitoramento agrometeorológico. http://www3.ceunes.ufes.br/estacao/ index2.asp?estacao=A617. 19 Ago. 2018.

Jiang, Z.P.; Li, Y.R.; Wei, G.P.; Liao, Q.; Su, T.M.; Meng, Y.C.; Zhang, H.Y.; Lu, C.Y. Effect of long-term vinasse application on physicochemical properties of sugarcane field soils. Journal Sugar Tech, v.14, n.4, p.412-417, 2012. https://doi.org/10.1007/s12355-0120174-9.
Lamaison, F.C.; Andrade, P.A.M.; Bigaton, A.D.; Andreote, F.D.; Antonio, R.V.; Reginatto, V. Long-term effect of acid and heat pretreatment of sludge from a sugarcane vinasse treatment plant on the microbial community and on thermophilic biohydrogen production. International Journal of Hydrogen Energy, v.40, n.41, p.14124-14133, 2015. https://doi.org/10.1016/j. ijhydene.2015.08.096.

Malavolta, E. O futuro da nutrição de plantas tendo em vista aspectos agronômicos, econômicos e ambientais. Informações Agronômicas, n.121, p.1-10, 2008. http://www.ipni.net/ PUBLICATION/IA-BRASIL.NSF/0/577D2D3419C67E5383257A900 07EAEFB/\$FILE/Page1-10-121.pdf. 10 Out. 2018.

Ministério da Agricultura, Pecuária e Abastecimento - Mapa. Balanço da cana-de-açúcar e agroenergia nacional. Brasília: MAPA; SPAE, 2007. 139p. http://www.agricultura.gov.br/assuntos/ sustentabilidade/agroenergia/balanco-nacional-da-cana-deacucar-e-agroenergia-2007. 12 Out. 2018.

Martinez, E.P.H.; Carvalho, J.G.; Souza, R.B. Diagnose foliar. In: Ribeiro, A.C.; Guimarães, P.T.G.; Alvarez, V. Recomendação para uso de corretivos e fertilizantes em Minas Gerais: 5a aproximação. Viçosa: CFSEMG, 1999. 359p.

Mendes, M.C.; Matchula, P.H.; Rossi, E.S.; Oliveira, B.R.; Silva, C.A.; Sékula, C.R. Adubação nitrogenada em cobertura associada com densidades populacionais de híbridos de milho em espaçamento reduzido. Revista Brasileira de Milho e Sorgo, v.12, n.2, p.92-101, 2013. https://doi.org/10.18512/1980-6477/rbms. v12n2p92-101.

Prezotti, L.C., Gomes, J.A., Dadalto, G.G., Oliveira, J.A. Manual de recomendação de calagem e adubação para o estado do Espírito Santo: 5a aproximação. Vitória: SEEA; INCAPER; CEDAGRO, 2007. 305p. http://biblioteca.incaper.es.gov.br/digital/ handle/123456789/3242. 10 Out. 2018.

Silva, A.P.M.; Bono, J.A.M.; Pereira, F.A. Aplicação de vinhaça na cultura da cana-de-açúcar: Efeito no solo e na produtividade de colmos. Revista Brasileira de Engenharia Agrícola e Ambiental, v.18, n.1, p.3843, 2014. https://doi.org/10.1590/S1415-43662014000100006.

Taiz, L.; Zeiger, E. Fisiologia vegetal. 5.ed. Porto Alegre: Artmed, 2013. $954 \mathrm{p}$.

Zhao, J.; Chen, S.; Hua, R.; Li, Y. Aggregate stability and size distribution of red soils under different land uses integrally regulated by soil organic matter, and iron and aluminum oxides. Soil \& Tillage Research, v.167, p.73-79, 2017. https://doi.org/10.1016/j. still.2016.11.007. 